\title{
Behavioral responses to variable predation risk in the California spiny lobster Panulirus interruptus
}

\author{
Chad L. Loflen ${ }^{1,2, *}$, Kevin A. Hovel ${ }^{1}$ \\ ${ }^{1}$ Department of Biology, San Diego State University, 5500 Campanile Drive, San Diego, California 92182, USA \\ ${ }^{2}$ Present address: California Water Quality Control Board-San Diego Region, 9174 Sky Park Court, Suite 100, San Diego, \\ California 92123, USA
}

\begin{abstract}
Shelter dwelling and gregariousness are behavioral strategies used by benthic marine organisms to reduce the risk of predator-induced mortality. For spiny lobsters, the relative and synergistic success of shelter dwelling and aggregation in reducing mortality may vary with the perceived risk of predation as well as the availability and size distribution of conspecifics and shelters. We tested how these factors influence antipredator behavior in the California spiny lobster Panulirus interruptus in southern California kelp forests. We measured shelter and lobster characteristics, predator density, relative lobster mortality outside of shelter, and quantified lobster antipredator behaviors in (1) the La Jolla Ecological Reserve (LJER), a marine protected area with high densities of large fishes known to be lobster predators, and (2) the Point Loma kelp forest, a nearby, heavily fished area. Predator densities and the relative mortality of tethered juvenile and adult lobsters were much higher in the LJER than in Point Loma, as was mean lobster size. In response to higher predation risk, solitary lobsters in the LJER used shelters more closely scaled to their body size than lobsters in Point Loma, thereby restricting predator access to shelters. In addition, aggregations of 2 or more lobsters were more frequent than expected by chance in the LJER, but not in Point Loma. Lobsters in Point Loma commonly were found outside of shelter during the day, whereas no lobsters ever were observed outside of shelter during daylight hours in the LJER. Overall, our results indicate that California spiny lobsters modify their antipredatory behaviors with level of predation risk and that behaviors designed to minimize predator-induced mortality are similar between California spiny lobsters and other spiny lobster species.
\end{abstract}

KEY WORDS: Spiny lobster $\cdot$ Predation $\cdot$ Shelter $\cdot$ Behavior $\cdot$ Panulirus interruptus $\cdot$ Tethering

\section{INTRODUCTION}

In many marine systems, predation directly and indirectly influences community structure (Paine 1974), prey and predator population dynamics (MacLulich 1937, Estes et al. 1998, Vucetich et al. 2005), and the behavior of prey and predatory organisms (Holbrook \& Schmitt 1988, Micheli 1997). For prey organisms, there are a variety of behavioral strategies that may reduce the risk of predator-induced mortality. Seeking shelter within or among structural elements of habitats, such as vegetation, dens, or crevices is one of the most common ways that prey species reduce mortality due to predation (e.g. Stein 1977, Garcia \& Sih 2003, Forrester \& Steele 2004). Many organisms form social groups (e.g. fish schools) in which cooperation among individuals can reduce the per capita risk of predation (Seghers 1974, Cote \& Jelnikar 1999, Kie 1999). Grouped prey may more efficiently detect predators and may more effectively ward off predators than solitary prey. Additionally, for prey organisms that aggregate in structured habitats to avoid predators, gregarious behavior may guide prey more quickly to refuge (Childress \& Herrnkind 1997).

For a given risk of predation, the relative and synergistic success of shelter dwelling and aggregation in 
reducing prey mortality will vary with availability and size distribution of conspecifics and the availability and size-distribution of shelters (Eggleston et al. 1990, Berger \& Butler 2001). However, the risk of predation seldom is consistent temporally and spatially, and prey therefore may alter their behavior depending on their perceived predation risk. For example, an organism's perceived risk of predation may change with body size if predators are incapable of preying upon larger individuals (Ryer 1988, Orth \& van Montfrans 2002). In Bahia de la Ascension, Mexico, solitary Caribbean spiny lobsters chose to inhabit smaller shelters scaled to their body size under conditions of high predation risk and low conspecific density, and chose to inhabit larger shelters that allowed aggregation under conditions of low predation risk and high conspecific density (Eggleston \& Lipcius 1992). Shelter-dwelling organisms that are vulnerable to predators, such as lobsters, therefore must decide among different behaviors for predator avoidance based on perceived risk of predation, conspecific density, and habitat availability and quality.

We examined California spiny lobster Panulirus interruptus (Randall, 1840) predator avoidance behavior and size distribution under variable regimes of predation risk in southern California kelp forests. The California spiny lobster (Crustacea: Decapoda: Palinuridae) is an ecologically and economically important species in southern California and Baja California, Mexico. Predation by $P$. interruptus alters community structure within the intertidal zone (Robles et al. 1990) and may play a strong role in structuring communities in kelp forests as well (Tegner \& Levin 1983, Halpern et al. 2006). California spiny lobster population size and mean size have decreased in response to heavy fishing pressure (Dayton et al. 1998). Thus, changes in predation pressure on California spiny lobsters may exacerbate the results of fishing and alter the intensities of top-down effects on subtidal and intertidal systems.

California spiny lobsters typically inhabit shelters during the day and emerge from shelters at dusk to forage (Allen 1916, Lindberg 1955). They may be found alone in shelter, but aggregations of 2 to 15 lobsters in shelters are common (Zimmer-Faust \& Spanier 1987). Though the behavioral defenses of other panulirids (e.g. Panulirus argus) have been extensively studied, relatively little is known about the California spiny lobster's behavioral and morphological defenses to predators, though shelter use, gregarious behavior (aggregations), and large body size all may deter predators (Winget 1968, Zimmer-Faust et al. 1985, Zimmer-Faust \& Spanier 1987, Spanier \& Zimmer-Faust 1988). Daytime aggregations by panulirids may minimize the risk of predator-induced mortality, particularly for younger individuals (Mitchell et al. 1969, Berrill 1975), by decreasing the per capita risk of predation (the dilution effect), enhancing group defense from predator attacks, and increasing vigilance against predators (Herrnkind et al. 2001). Antennae 'posturing' by $P$. interruptus also may be a form of defense against predators (Spanier \& Zimmer-Faust 1988, C. L. Loflen pers. obs.). Additionally, P. interruptus is able to chemically detect conspecifics (Zimmer-Faust et al. 1985), which as for other panulirids, may quickly guide lobsters to suitable shelter, a process termed the 'guide effect' (Nevitt et al. 2000, Childress \& Herrnkind 2001).

To examine how lobster behavior and size distribution varied with predation risk, we took advantage of large-scale differences in the abundance of top predators in the kelp forests of southern California. Our study sites within the La Jolla kelp forest were within the boundaries of the La Jolla Ecological Reserve (LJER), a small $\left(2.16 \mathrm{~km}^{2}\right)$ no-take marine protected area (MPA) established in 1973 at the northern end of the kelp forest. This MPA was established in response to diminishing populations of abalone and large predatory fishes such as California sheephead Semicossyphus pulcher and black sea bass Stereolepis gigas, both predators of spiny lobsters that are abundant in the MPA (Parnell et al. 2005). In contrast, the Point Loma (PL) kelp forest, 10 $\mathrm{km}$ to the south of the LJER, remains open to both commercial and recreational fishing and has vastly reduced densities of large predatory fishes (Dayton et al. 1998, C. L. Loflen pers. obs.). We conducted surveys and predation experiments in the LJER and in PL to determine whether differences in lobster predation risk exist between the 2 sites and whether these differences influence lobster antipredator behavior. Specifically, at each site we quantified (1) predator abundance, (2) relative lobster mortality, (3) lobster density and size distribution, (4) shelter characteristics, and (5) lobster shelter selection behavior.

\section{MATERIALS AND METHODS}

Study sites. Our surveys and experiments took place from June to September 2006 in the LJER and in PL (Fig. 1). The kelp forest at both sites is dominated by the surface canopy-forming giant kelp Macrocystis pyrifera and by 2 understory kelps, Pterygophora californica and Laminaria farlowii, growing at ca. 9 to $20 \mathrm{~m}$ depth (Stewart 1991, Dayton et al. 1992). The intertidal and shallow subtidal shorelines have extensive surfgrass Phyllospadix torreyi habitat that is used by juvenile and adult lobsters (Parker 1972, Serfling 1972, Engle 1979). Mean monthly water temperatures can range from 10 to $22^{\circ} \mathrm{C}$, though temperatures below the thermocline rarely exceed $16^{\circ} \mathrm{C}$ (Stewart 1991). The 


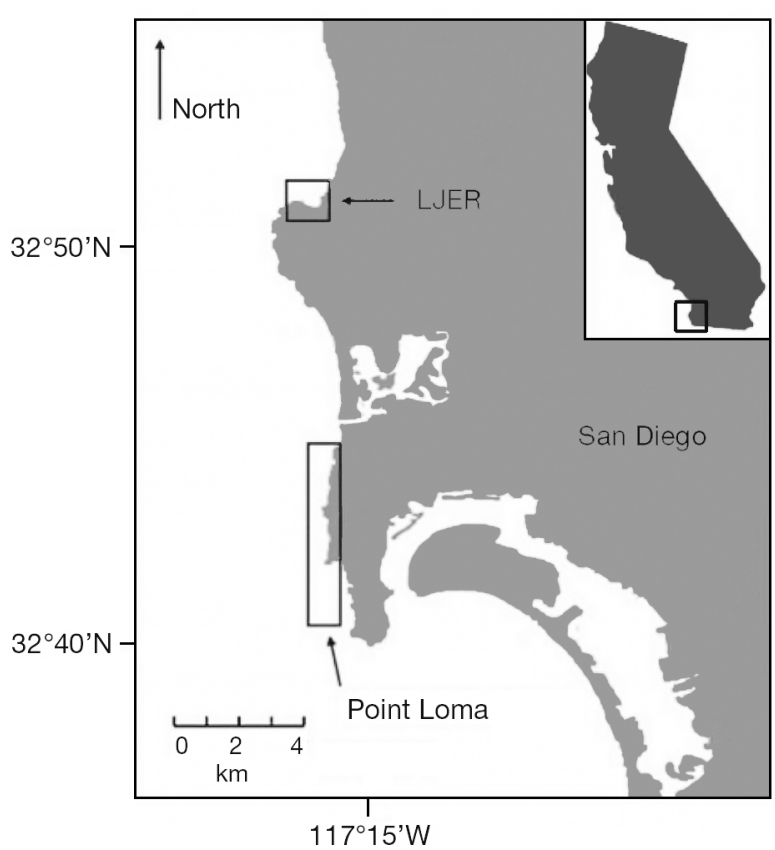

Fig. 1. The Point Loma kelp forest and the La Jolla Ecological Reserve (LJER) study sites in San Diego, CA, USA $\left(32.69^{\circ} \mathrm{N}\right.$, $\left.117.26^{\circ} \mathrm{W}\right)$

substratum consists of gently sloping sandstone with scattered cobble to boulder-sized rocks of varying densities. Stacked cobble and boulders, ledges, and hollowed-out $M$. pyrifera holdfasts serve as lobster shelters. Commercial and recreational fishing for lobsters takes place in PL from October to March. Studies at both locations were conducted using SCUBA diving.

Relative lobster mortality. We used tethering to determine whether relative mortality rates of lobsters outside of shelter varied between the LJER and PL, and between juvenile (4 to $5 \mathrm{~cm}$ carapace length, CL) and adult ( 7 to $8 \mathrm{~cm} \mathrm{CL}$ ) lobsters. Tethering is frequently used to compare relative rates of crustacean mortality (e.g. crabs: Pile et al. 1996, Hovel \& Lipcius 2001; lobsters: Mintz et al. 1994, Lipcius et al. 1998, Diaz et al. 2005) but does not measure absolute mortality rates because tethered prey cannot flee from predators. Lobsters were captured by hand ca. $24 \mathrm{~h}$ before experiments began and held in a recirculating aquarium. We tethered lobsters by cinching a noose composed of $36 \mathrm{~kg}$ braided fishing line around the carapace and then gluing the noose to the top of the carapace using cyanoacrylate glue. A $30 \mathrm{~cm}$ extension of the noose then was tied to a stake affixed to the substratum. We tethered 4 replicate lobsters within each of 21 haphazardly located plots in the LJER and PL. Lobsters in plots were tethered no less than $14 \mathrm{~m}$ apart and plots were never reused. As our goal was to assess relative predation risk between sites for lobsters outside of shelter, all understory algae within a $1 \mathrm{~m}$ radius around tethered lobsters was cleared at the start of each trial. Each trial lasted $7 \mathrm{~d}$ and there were a total of 11 and 10 trials in the LJER and PL, respectively, for a total of 40 lobsters ( $\mathrm{n}=20$ per size class) in the LJER and 44 ( $\mathrm{n}=$ 22 per size class) in PL. Lobsters not consumed after $7 \mathrm{~d}$ were released at the point of capture. After $7 \mathrm{~d}$ we recorded the state of the lobster as alive (whole, active lobster remaining on the tether), eaten (fragment of the carapace remaining on the tether), missing (no lobster or fragment remaining on the tether), or molted (entire carapace remaining on the tether). Molted lobsters were excluded from the analysis. Previous work with California spiny lobsters indicated that they could only escape from a tether via molting and that there was no indication of tethering inducing molting or mortality within a 7 d tethering period (Mai \& Hovel 2007). We tethered an additional 6 lobsters in control cages and found no mortality or escapes from tethers. Additionally, video analysis of tethered lobsters (see section below) revealed that large fish predators often remove lobsters entirely from tethers. We therefore assumed that missing lobsters were taken away by predators. We tested for differences in relative lobster mortality between the LJER and PL and between juvenile and adult lobsters using a $G$-test.

Video analysis. We tethered an additional 3 lobsters in the LJER and 5 lobsters in PL and used a digital video camera in a waterproof housing to identify lobster predators, evaluate length of time before a predator encounter, and to enumerate predator strikes on lobsters in each region to qualitatively assess if there was any treatment-specific bias between regions (Peterson \& Black 1994).

Lobster, predator, and shelter surveys. We conducted surveys in the LJER and PL to quantify patterns of shelter density and lobster density, size distribution, and shelter use. We also conducted surveys for large predatory fishes in each location to estimate potential predator density, and thus the perceived predation risk for lobsters surveyed. Surveys at both locations were done in depths of 9 to $14 \mathrm{~m}$. In PL, we counted lobsters and potential lobster shelters in 12 haphazardly chosen sites $(20 \times 20 \mathrm{~m})$ located no less than $100 \mathrm{~m}$ apart (Mai $\&$ Hovel 2007). At each site, divers searched for shelters and lobsters by swimming 4 parallel $5 \times 20 \mathrm{~m}$ transects, covering the entire $400 \mathrm{~m}^{2}$. Divers recorded the number of lobsters per shelter and also searched for lobsters outside of shelter by turning over understory algae while conducting the transects. Lobster CL was measured to the nearest $0.5 \mathrm{~cm}$ with a ruler. Lobster shelters were characterized as (1) ledge (cracks in the reef forming permanent crevices or overhangs), (2) rock (spaces between rocks or between rocks and the substratum), or (3) holdfast (giant kelp holdfasts 
hollowed out by grazing sea urchins). Lobsters commonly are found in all 3 of these shelter types in southern California (Mai \& Hovel 2007). For each shelter, we recorded shelter dimensions by taking 3 haphazard measurements each for depth, opening height, and width. Empty shelters were measured and investigated for organisms that can competitively exclude lobsters (e.g. octopus). In the LJER, lobster and shelter surveys were identical to those conducted in PL except that, due to the smaller size of the kelp forest, we counted lobster and shelters in 13 haphazardly chosen $4 \times 20 \mathrm{~m}$ sites located no less than $50 \mathrm{~m}$ apart.

To quantify the abundance of potential lobster predators in the LJER and PL, we counted the number of California sheephead Semicossyphus pulcher, black sea bass Stereolepis gigas, horn sharks Heterodontus francisci, kelp bass Paralabrax clathratus, cabezon Scorpaenichthys marmoratus, and ling cod Ophiodon elongatus observed within transects at the same sites used to survey lobsters and shelters. These abundant fishes represent the majority of large-bodied potential lobster predators in southern California (Winget 1968, Cowen 1986). Potential lobster predators not accounted for in these surveys included octopuses Octopus spp. and the California sea lion Zalophus californianus. Fishes $<30 \mathrm{~cm}$ in length were not considered potential predators of juvenile and adult lobsters, based on video analysis of potential predator strikes (see 'Video analysis' above) and from previous tethering experiments (Mai \& Hovel 2007). Surveys were made by swimming slowly along the bottom and counting the number of potential predators of each species within a $4 \times 20 \mathrm{~m}$ transect and up to $4 \mathrm{~m}$ above the substratum (Parnell et al. 2005). While some large fishes may remain out of visual range of divers, and fish behavioral differences between MPA and non-MPA locations may make comparisons among locations conservative (Kulbicki 1998), survey by SCUBA diving is the most effective method for estimating large fish densities in southern California kelp forests (Davis \& Anderson 1989).

To compare lobster and shelter characteristics between the 2 sites, we used a multivariate analysis of variance (MANOVA), followed by 2-tailed $t$-tests, to test for differences in mean lobster density, mean shelter density, and mean lobster CL between the LJER and PL. Data were log-transformed when necessary to meet test assumptions in these and all subsequent tests. Assumptions of normality were evaluated visually while those of homogeneity of variances were evaluated using the $F$-test. We further examined shelter characteristics by performing a KolmogorovSmirnov (K-S) test to detect differences in the distributions of available shelter volumes between sites. To determine whether solitary lobster shelter use varied between the 2 sites, we began by testing whether mean shelter opening height differed between the 2 sites with a 2-tailed $t$-test and then tested whether solitary lobsters used shelters more closely scaled to their body size in the LJER than in PL (Eggleston et al. 1990). To do so, we used linear regression to test for correlations between lobster CL (dependent variable) and shelter aperture (opening) height (independent variable). We chose shelter aperture height as the independent variable, rather than shelter volume, width, or depth, because shelters with lower entrance height restrict access to large fishes, and Caribbean spiny lobsters that chose shelters with an aperture height scaled closely to body size received greater protection from fish predators than lobsters selecting taller shelters (Eggleston et al. 1990, Mintz et al. 1994). We tested for differences between the 2 locations by comparing the equality of the slopes between the 2 best-fit regression lines using a $t$-test (Zar 1999). The data for this analysis were limited to lobsters with the same range of CL between the 2 sites (i.e. 5.5 to $8.5 \mathrm{~cm} \mathrm{CL).}$ Additionally, we used separate chi-square tests for independence to test for differences in (1) the proportion of solitary lobsters that were juveniles, (2) the proportion of aggregations ( 2 or more lobsters) containing at least one adult lobster, and (3) the number of lobsters found outside of shelter during the day between the LJER and PL. We also compared the distribution of aggregation sizes with the Poisson distribution utilizing a chi-square goodness-of-fit test to determine if lobster aggregations were significantly larger than those expected by chance (Zimmer-Faust et al. 1985, Zimmer-Faust \& Spanier 1987). Lastly, we used separate chi-square tests for independence (one for each species) to test for differences in predator presence between the 2 sites. Yates correction was used when necessary to adjust analyses for low predator abundance.

\section{RESULTS}

\section{Relative lobster mortality}

Of all lobsters tethered, only one escaped via molting, and no lobsters tethered in control cages escaped from tethers, died, molted, or were eaten. Mortality from predation was significantly higher for juvenile and adult lobsters in the LJER than in PL, but there was no difference in mortality between juvenile and adult stages and no interactive effect of site and stage (G-test, Stage: $\mathrm{df}=1, G=0.27, \mathrm{p}=0.27 ;$ Site: $\mathrm{df}=1, G=$ 57.72, p < 0.001; Site $\times$ Stage: $\mathrm{df}=1, G=0.26 \mathrm{p}=0.61$; Fig. 2). In the LJER, $89.5 \%$ of adult lobsters and $100 \%$ of juvenile lobsters were eaten within $1 \mathrm{wk}$ of tethering, 


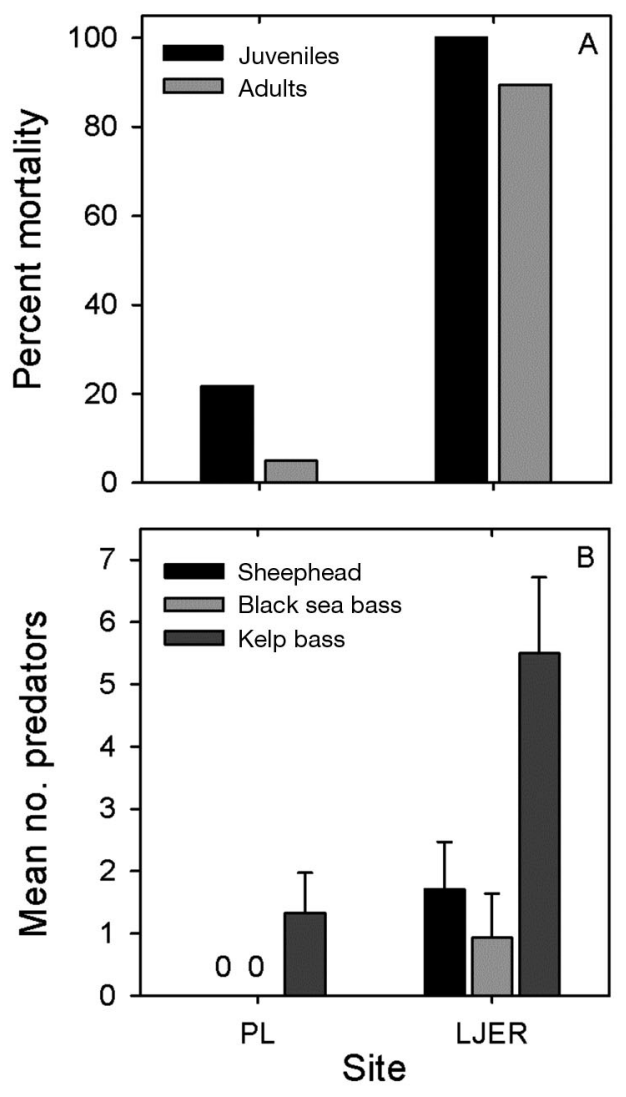

Fig. 2. (A) Relative percent mortality for juvenile and adult spiny lobsters Panulirus interruptus in tethering experiments conducted in the Point Loma (PL) kelp forest and the La Jolla Ecological Reserve (LJER). (B) Mean (+SE) number of potential predators per $20 \mathrm{~m}$ transect at the 2 sites

compared to $5 \%$ of adults eaten and $29.4 \%$ of juveniles eaten in PL. In the qualitative video analysis, California sheephead were the primary predator in the LJER, typically consuming lobsters within $1 \mathrm{~h}$ of tethering. In PL, no lobsters were consumed or attacked in a total of $450 \mathrm{~min}$ of video analysis.

\section{Predator surveys}

The abundance of potential predators was far higher in the LJER than in PL (Fig. 2). Divers observed potential predators on $100 \%$ of transects in the LJER, whereas only $58.3 \%$ of all PL transects contained potential predators (Yates-corrected chi-square, $\mathrm{df}=1$, $\chi^{2}=4.79, \mathrm{p}=0.029$ ). Large numbers of California sheephead and black sea bass were present in the LJER but were entirely absent in our surveys in PL. Kelp bass were present at both sites, but their densities were 4 -fold higher in the LJER than in PL ( $t$-test: $\mathrm{df}=$ 1,24, $t=3.38, \mathrm{p}=0.002$; Fig. 2).
Table 1. Panulirus interruptus. Results of $t$-tests for differences in lobster characteristics, site characteristics, and lobster shelter use between the La Jolla Ecological Reserve and the Point Loma kelp forest

\begin{tabular}{|lrrr|}
\hline Factor & df & \multicolumn{1}{c}{$t$} & \multicolumn{1}{c|}{$\mathrm{p}$} \\
\hline Mean lobster density & 23 & 1.23 & 0.22 \\
Mean lobster size & 270 & 9.8 & $<0.01$ \\
Mean shelter density & 23 & 3.1 & $<0.01$ \\
Mean shelter volume & 284 & 1.96 & 0.05 \\
Mean shelter height & 284 & 0.08 & 0.93 \\
\hline
\end{tabular}

\section{Lobster and shelter characteristics}

Over the course of our surveys, we counted and measured 151 shelters and 125 lobsters in the LJER, and 147 shelters and 153 lobsters in PL. Collectively, lobster density, shelter density, and CL differed between sites (MANOVA: df =3,21, $F=4.429$; $\mathrm{p}<0.05$ ). Mean lobster density was 3 -fold higher in the LJER than in PL, but the trend was weakened by high within-site variance in the LJER (Table 1, Fig. 3). We found strong evidence for greater mean lobster CL in the LJER than in PL (Table 1, Fig. 4). We compared mean lobster CL at each site to average size at reproductive maturity for California spiny lobsters (6.5 cm CL; Barsky 2001) and found that lobsters in the LJER were on average significantly larger than the size of reproductive maturity ( $\mathrm{df}=119, t=5.9, \mathrm{p}<0.001$ ), while average size of lobsters in PL was significantly smaller than the size of reproductive maturity ( $\mathrm{df}=151, t=8.2, \mathrm{p}<0.001$ ).

We found strong evidence for higher shelter density in the LJER than in PL (Table 1, Fig. 3) and marginally strong evidence that mean shelter volume was larger in the LJER than in PL (Table 1, Fig. 5), but little evi-

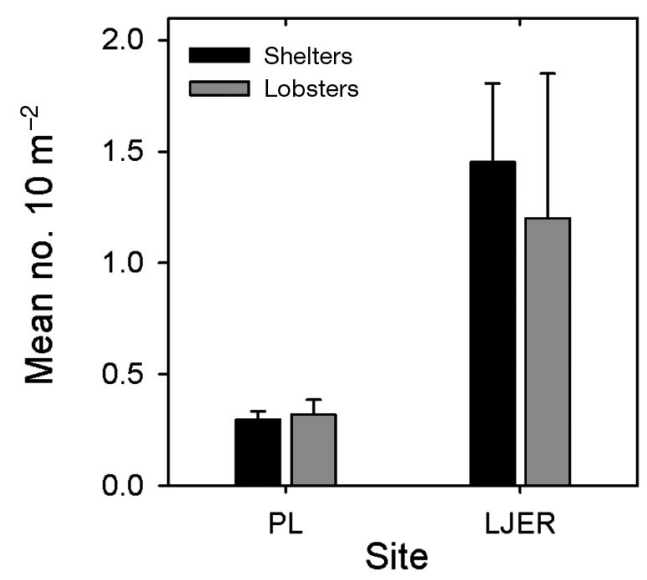

Fig. 3. Panulirus interruptus. Mean (+SE) California spiny lobster density and mean shelter density in the Point Loma kelp (PL) forest and the La Jolla Ecological Reserve (LJER) 


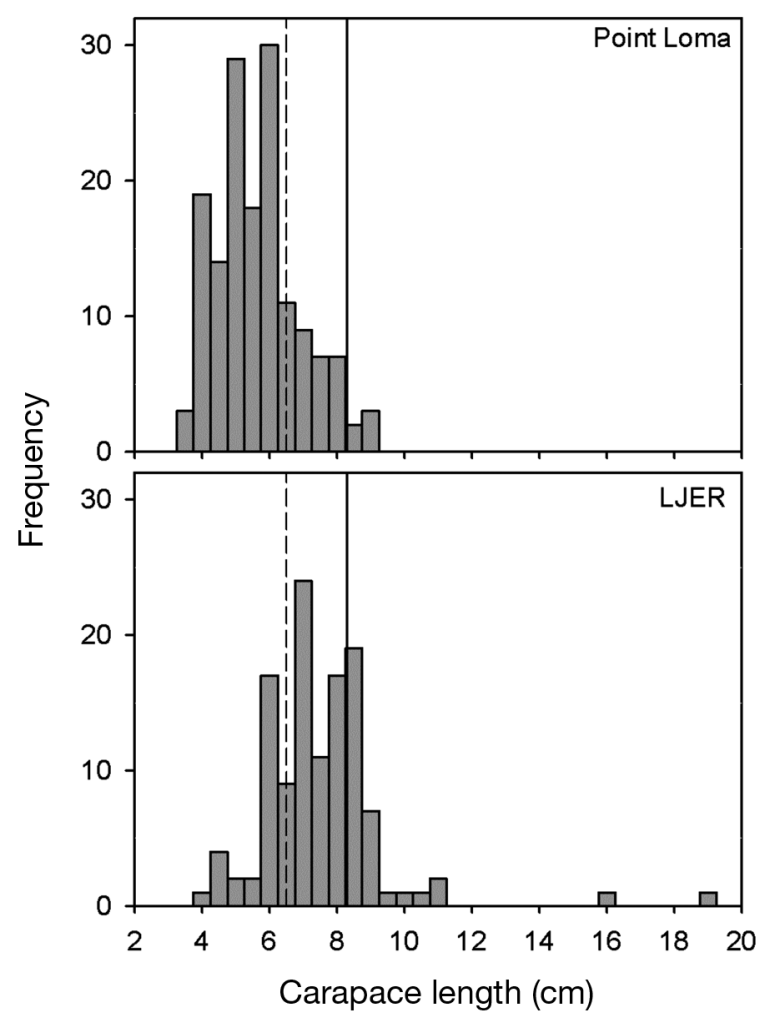

Fig. 4. Panulirus interruptus. Size-frequency distribution of spiny lobster carapace length (CL) for the Point Loma kelp forest and the La Jolla Ecological Reserve (LJER). Solid vertical line represents the minimum size of a lobster legally taken by the fishery $(8.3 \mathrm{~cm})$; dashed vertical line represents the minimum CL of reproductively active lobsters $(6.5 \mathrm{~cm})$

dence for a difference in the distribution of shelter volumes available at each site $(\mathrm{K}-\mathrm{S} Z$ statistic $=0.12, \mathrm{p}=$ 0.24). There was also no evidence that mean shelter aperture height differed between sites (Table 1). The proportion of available shelters occupied by lobsters was relatively low at both the LJER and PL, with 27.1 and $39.1 \%$ of available shelters surveyed being occupied, respectively.

\section{Lobster behavior}

Though mean shelter height was nearly identical between the 2 sites, we found strong evidence that solitary lobsters use shelters more closely scaled to body size in the LJER. Shelter aperture height and lobster CL for solitary lobsters in the LJER were significantly correlated $\left(\mathrm{df}=1,21, F=3.6, \mathrm{r}^{2}=0.11, \mathrm{p}=0.07\right.$; Fig. 6), though much of the variation in shelter aperture height remained unexplained. In contrast, no correlation between shelter aperture height and lobster

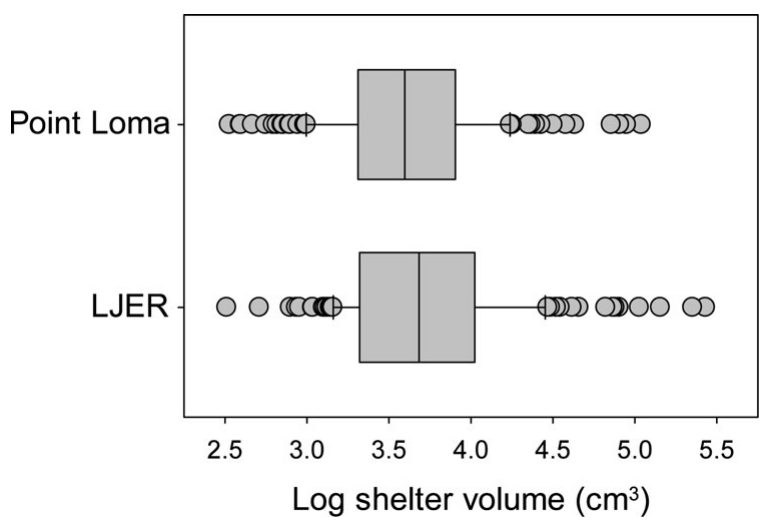

Fig. 5. Shelter-volume distribution for all available shelters surveyed in the Point Loma kelp forest and the La Jolla Ecological Reserve (LJER). Box limits: 25th/75th percentiles; whiskers: 10th/90th percentiles; middle box line: median; circles: outliers

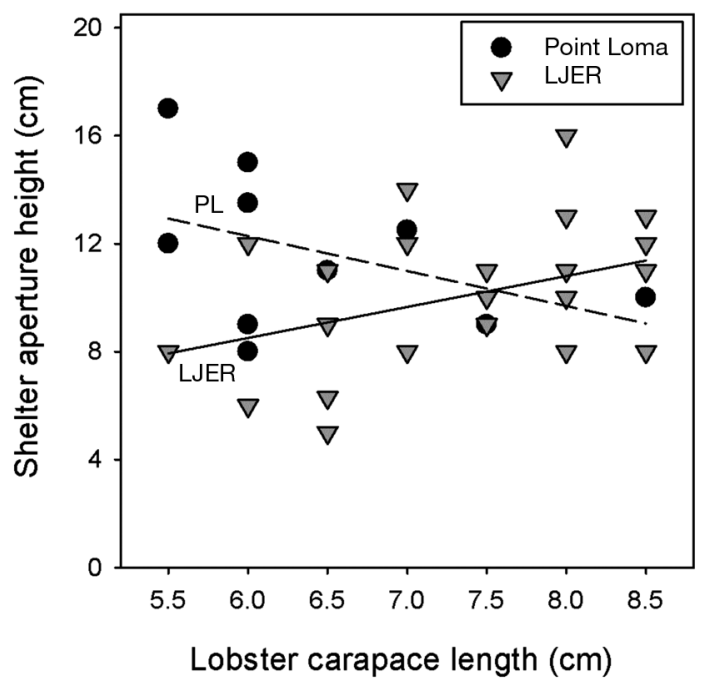

Fig. 6. Panulirus interruptus. Scatterplot of solitary spiny lobster carapace length versus shelter aperture height for the Point Loma (PL) kelp forest and the La Jolla Ecological Reserve (LJER). Dashed line for non-significant correlation in PL is shown to illustrate significantly different slopes of best fit lines for the 2 sites

CL for solitary lobsters existed in PL $(\mathrm{df}=1,8, F=1.8$, $r^{2}=0.08, p=0.22$; Fig. 6). Slopes of the best-fit regression lines for shelter aperture height versus lobster CL differed between the 2 sites ( $\mathrm{df}=29, t=18.4, \mathrm{p}<$ 0.001). Aggregations were more common than expected by chance in the LJER $\left(\mathrm{df}=4, \chi^{2}=14.569, \mathrm{p}<\right.$ 0.01 ) but not in PL ( $\mathrm{df}=4, \chi^{2}=6.677, \mathrm{p}=0.15$; Fig. 7 ). All aggregations ( 2 or more lobsters) in the LJER contained at least 1 adult lobster, whereas in PL only $62 \%$ of aggregations contained at least 1 adult (Table 2). 


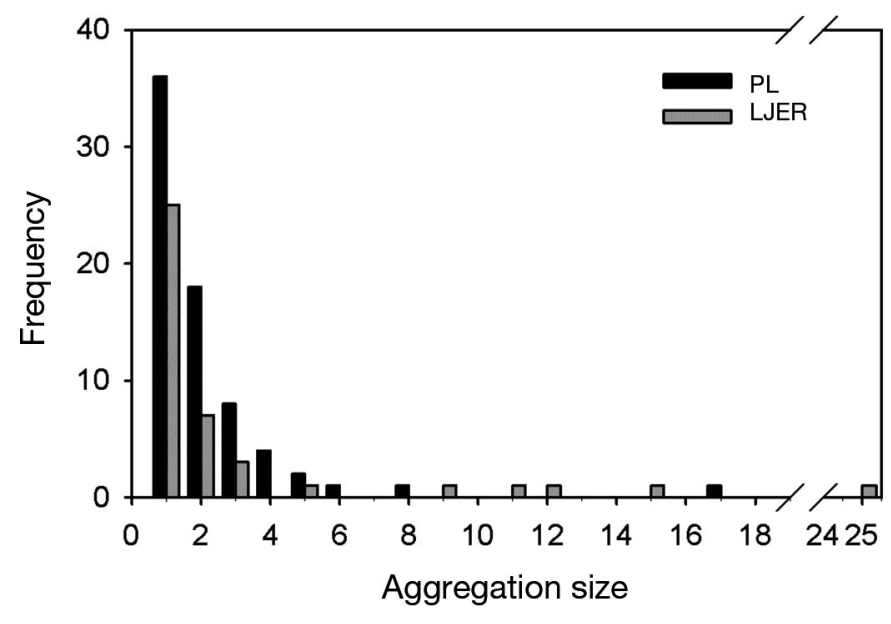

Fig. 7. Panulirus interruptus. Frequency of California spiny lobster aggregation sizes in the Point Loma (PL) kelp forest and the La Jolla Ecological Reserve (LJER)

There was also strong evidence for more lobsters outside of shelter in PL than in the LJER: In the LJER, no lobsters were witnessed outside of shelter, while in PL, $11.7 \%$ of lobsters surveyed were not in shelter, but instead were moving or stationary in unsheltered habitat during daylight hours (Table 2). Finally, the proportion of solitary lobsters classified as juveniles $(<6.5 \mathrm{~cm}$ CL) was significantly lower in the LJER than in PL (Table 2).

\section{DISCUSSION}

Our primary finding in this study is that behavioral aspects of lobster shelter use varied between 2 kelp forest locations in southern California that differed substantially in predation risk. We found that the abundance of large predatory fishes and the relative mortality risk for lobsters were substantially higher in a small marine reserve (the LJER) than in nearby PL. Concomitantly, lobsters in the LJER selected shelters closely scaled to body size and more frequently inhabited shelters in aggregations than lobsters in PL. Lob- sters in the LJER also were never observed venturing from shelter during the day, a behavior seen frequently during the day in PL.

An important caveat in our study is that we worked at only 2 sites, and therefore we cannot definitively ascribe patterns of lobster shelter use to mortality risk. Many factors that may influence shelter use likely differ among the 2 kelp forests in addition to predator abundance and risk of mortality outside of shelter, including lobster density, substratum rugosity, and the density of potential prey such as urchins (Nichols 2009). There also may have been aspects of potential lobster shelters that varied between sites that we did not quantify, as well as other features of the benthos, such as the density of understory algae, which may influence lobster mortality and behavior.

Despite covariation among a number of factors that differ between the LJER and PL, several lines of evidence suggest that strong differences in predator abundance and in relative mortality risk remain the most compelling reasons for differences in lobster shelter use behavior. First, altered patterns of shelter use form the basis of behavioral responses to predation risk in other lobster species, such as the Caribbean spiny lobster Panulirus argus (Eggleston \& Lipcius 1992, Smith \& Herrnkind 1992, Childress \& Herrnkind 1997), the rock lobster Jasus edwardsii (Kelly et al. 1999), and the American lobster Homarus americanus (Spanier et al. 1998). For instance, when predation pressure was low in manipulative experiments, solitary $P$. argus chose large shelters suitable for future cohabitation (Eggleston \& Lipcius 1992). However, when a predatory nurse shark was present, lobsters chose smaller, artificial shelters that were more scaled to their body size, as the relative mortality of juvenile lobsters was dependent upon the size of shelters in which they were tethered (see also Eggleston et al. 1990). Eggleston et al. (1997) found the same trend for increasing use of smaller, artificial shelters by solitary Caribbean spiny lobsters at sites with enhanced densities of predatory Nassau grouper in Sugar Cay Bay, Bahamas. Ours is the first study to test spiny lobster shelter scaling in response to mortality risk in naturally occurring shel-

Table 2. Panulirus interruptus. Results of chi-square tests on California spiny lobster shelter use behavior within the La Jolla Ecological Reserve (LJER) and the Point Loma kelp forest (PL)

\begin{tabular}{|c|c|c|c|c|c|}
\hline Variable & LJER (\%) & PL (\%) & $\mathrm{df}$ & $\chi^{2}$ & $\mathrm{p}$ \\
\hline Aggregations with: $\geq 1$ adult $^{\mathrm{a}}$ & 100 & 62 & 1 & 8.3 & 0.004 \\
\hline Lobsters outside of shelter & 0 & 11.7 & 1 & 15.7 & $<0.001$ \\
\hline Solitary juvenile lobsters ${ }^{\mathrm{b}}$ & 16.6 & 73.7 & 1 & 14.7 & $<0.001$ \\
\hline
\end{tabular}


ters, rather than artificial shelters. In our study, shelter height scaled with lobster body size where predation risk was high; in particular, smaller, vulnerable lobsters selected shelters with reduced aperture heights in the LJER as compared to lobsters in PL. Shelter aperture height may be the most important aspect of shelter size for lobsters; shelters with lower aperture height restricted predator access to Caribbean spiny lobsters in Bahia de la Ascension, Mexico (Eggleston et al. 1990), in Florida Bay (Mintz et al. 1994), and in Sugar Cay Bay (Eggleston et al. 1997). Differences in lobster shelter selection between the LJER and PL decreased as lobster body size increased, most likely because large lobsters have some size refuge from predation, particularly when occupying shelter.

A second reason to suspect that predation risk drives differences in lobster behavior between sites is that aspects of gregarious shelter dwelling, another antipredator behavior, differed between the LJER and PL. We found that the frequency of aggregations was greater than expected by chance in the LJER but not in $\mathrm{PL}$, despite the higher density of potential shelters present in the LJER. Lobsters were not forced to form larger aggregations in the LJER than in PL, as shelter volumes were similar between the 2 sites, and many available shelters were unoccupied at both sites. Similarly, in large experimental arenas in Long Key, Florida, USA, lobsters were solitary or formed small groups when triggerfish predators were absent, but formed larger aggregations and limited their movements from shelter when triggerfish were present (Herrnkind et al. 2001). In Florida Bay, Caribbean spiny lobsters aggregated under large artificial shelters at sites with high predator abundance and high conspecifc density, and aggregations reduced proportional mortality of lobsters (Mintz et al. 1994). However, when predator abundance increased substantially and conspecific density decreased, lobster abundance within smaller, artificial shelters increased.

Third, we found lobsters outside of shelter during the day in PL, but not in the LJER. Lobsters and other shelter-dependent organisms may respond to reduced predation risk by reducing time spent in shelter (Herrnkind et al. 2001) and may gain an advantage over sheltered conspecifics via increased time spent foraging in productive habitats or an ability to move over larger distances. The presence of submerged vegetated habitat appears to influence whether California spiny lobsters emerge from shelter and which shelters they occupy during the day. For instance, lobsters outside of shelter during the day in PL invariably are found near or under understory algae (e.g. Eisenia arborea and Pterygophora californica) or within surfgrass Phyllospadix spp. beds, 2 habitats that afforded tethered lobsters protection from predators compared to unvegetated areas (Mai \& Hovel 2007, Withy-Allen 2010). Moreover, for those lobsters that remained in shelter during the day in PL, abundance within rocky shelters at the landscape scale (i.e. $20 \times 20 \mathrm{~m}$ areas) was positively correlated with the cover of canopyforming understory kelp (Mai \& Hovel 2007). Similarly, canopy-forming understory kelps also were abundant in the LJER and increased relative survival of lobsters compared to unvegetated areas; however, lobster shelter selection was influenced by the presence of the non-canopy forming alga Plocamium pacificum, which lobsters do not inhabit during the day, but which they use as foraging grounds at night to feed on small mollusks and crustaceans (Withy-Allen 2010).

We also found that juvenile lobsters exhibited strong differences in shelter-dwelling behavior between the 2 sites. Juvenile lobsters likely are vulnerable to a larger size-range of predators or at least may have a higher perceived risk of predation than larger lobsters. Relative mortality of tethered juveniles was higher than that of adults both in the LJER and at PL, though the difference was not statistically significant at either site (see also Withy-Allen 2010), and the relative mortality of juveniles in PL was much lower than LJER. Juveniles commonly occupied shelters alone in PL, but rarely did so in the LJER, and when this occurred in the LJER, they selected smaller shelters than did juveniles in PL. Moreover, aggregations consisting only of juveniles (as opposed to aggregations including at least 1 adult) were absent from the LJER but relatively common in PL. Though we cannot determine if this is a response to predation risk or to the fact that juvenile lobsters are more common at PL than in the LJER, juvenile Caribbean spiny lobsters experienced enhanced survival when sheltering in groups that included adult lobsters (Briones-Fourzan \& Lozano-Alverez 2008). In contrast, Childress \& Herrnkind (2001) found that juvenile Caribbean spiny lobsters benefited from gregarious shelter dwelling only via the guide effect (whereby searching lobsters locate shelters most quickly when they are occupied by conspecifics) rather than from enhanced rates of survival. However, modeling by Dolan \& Butler (2006) predicted juvenile Caribbean spiny lobsters to benefit from enhanced survival via the guide effect only under conditions of low shelter density, longer shelter search period, and high predation risk.

Our results suggest that lobsters have made a major behavioral adjustment to reduced predation risk in PL. In contrast, present levels of predation risk for lobsters in the LJER may be similar to historical levels throughout southern California, particularly at times when large predatory fishes were still common in areas such as PL (Dayton et al. 1998). For example, at the turn of the 20th century, black sea bass and sheephead were 
common in PL, and many reportedly had up to one dozen lobsters in their stomachs (Allen 1916). Sheephead are the dominant diurnal predator of California spiny lobsters and sea urchins, and their presence strongly deters lobster and urchin movement from shelter during the day (Allen 1916, Tegner \& Levin 1983). Spiny lobsters may fill at least part of the role played by sheephead, which are now largely absent from PL, in top-down regulation of kelp forest communities (Tegner \& Dayton 1981), particularly if daytime foraging by a subset of lobsters has led to increased lobster predation on herbivores such as the purple sea urchin Strongylocentrotus purpuratus. However, further research is necessary to determine how these behavioral shifts may alter benthic communities.

Though our study was too limited to suggest whether shelter use behavior is likely to differ between MPA and non-MPA sites in general, our results suggest that research on the effects of MPAs on benthic communities should consider how the establishment of MPAs may lead to changes in organism behavior and abundance. Higher-order predators, in particular, are often more abundant inside versus outside of MPAs (Cole et al. 1990, Babcock et al. 1999, Paddack \& Estes 2000, Parnell et al. 2005), which can potentially induce indirect effects within these areas that should be studied further. Trait-mediated, indirect effects, including habitat selection, time spent outside of shelter, and prey choice by mesopredatory organisms such as lobsters, may have significant roles to play in how benthic communities respond to MPA establishment.

Acknowledgements. This work was supported by a research grant to K.A.H. from California Sea Grant. Many thanks go out to K. Palaoro and B. Cheng for their assistance diving in the field and working in the laboratory. We also thank $\mathrm{T}$. Anderson, D. Deutschman and D. Moellendorf for comments on a previous version of the manuscript, and the San Diego State University diving and boating program for equipment servicing and provision of SCUBA cylinders. This is a contribution from the San Diego State Coastal and Marine Institute.

\section{LITERATURE CITED}

Allen BM (1916) Notes on the spiny lobster Panulirus interruptus of the California coast. Univ Calif Publ Zool 16: $139-152$

Babcock RC, Kelly S, Shears NT, Walker JW, Willis TJ (1999) Changes in community structure in temperate marine reserves. Mar Ecol Prog Ser 189:125-134

Barsky KC (2001) California spiny lobster. In: Leet WS, Dewees CM, Klingbeil R, Larson EJ (eds) California's living marine resources: a status report. California Department of Fish and Game, University of California, Oakland, CA, p 98-100

Berger D, Butler M (2001) Octopuses influence den selection by juvenile Caribbean spiny lobster. Mar Freshw Res 52: 1049-1053
Berrill M (1975) Gregarious behavior of juveniles of the spiny lobster, Panulirus argus (Crustacea: Decapoda). Bull Mar Sci 25:515-522

Briones-Fourzan P, Lozano-Alvarez E (1998) Coexistence of congeneric spiny lobsters on coral reefs: differences in conspecific aggregation patterns and their potential antipredator benefits. Coral Reefs 27:275-287

Childress MJ, Herrnkind WF (1997) Den sharing by juvenile Caribbean spiny lobsters (Panulirus argus) in nursery habitat: cooperation or coincidence? Mar Freshw Res 48: 751-758

Childress MJ, Herrnkind WF (2001) The guide effect influence on the gregariousness in juvenile Caribbean spiny lobsters. Anim Behav 62:465-472

Cole RG, Ayling TM, Creese RG (1990) Effects of marine reserve protection at Goat Island, northern New Zealand. NZ J Mar Freshw Res 24:197-210

> Cote I, Jelnikar E (1999) Predator-induced clumping behavior in mussels (Mytilus edulis Linnaeus). J Exp Mar Biol Ecol 235:201-211

Cowen RK (1986) Site-specific differences in the feeding ecology of the California sheephead, Semicossyphus pulcher (Labridae). Environ Biol Fishes 16:193-203

Davis GE, Anderson TW (1989) Population estimates of four kelp fishes and an evaluation of three in situ assessment techniques. Bull Mar Sci 44:1138-1151

Dayton PK, Tegner MJ, Parnell PE, Edwards PB (1992) Temporal and spatial patterns of disturbance and recovery in a kelp forest community. Ecol Monogr 62:421-445

> Dayton PK, Tegner MJ, Edwards PB, Riser KL (1998) Sliding baselines, ghosts and reduced expectations in kelp forest communities. Ecol Appl 8:309-322

Diaz D, Zabala M, Linares C, Hereu B (2005) Increased predation of juvenile European spiny lobster (Panulirus elephas) in a marine protected area. NZ J Mar Freshw Res 39: 447-453

Dolan TW, Butler MJ (2006) The adaptive value of aggregation among juvenile Caribbean spiny lobster: an evaluation using individual-based modeling. J Crustac Biol 26: 565-578

Eggleston DB, Lipcius RN (1992) Shelter selection by spiny lobster under variable predation risk, social conditions and shelter size. Ecology 73:992-1011

Eggleston DB, Lipcius RN, Miller DL, Coba-Cetina L (1990) Shelter scaling regulates survival of juvenile Caribbean spiny lobster Panulirus argus. Mar Ecol Prog Ser 62:79-88

Eggleston DB, Lipcius RN, Grover JJ (1997) Predator and shelter-size effects on coral reef fish and spiny lobster prey. Mar Ecol Prog Ser 149:43-59

Engle JM (1979) Ecology and growth of juvenile California spiny lobster, Panulirus interruptus (Randall). PhD dissertation, University of Southern California, Los Angeles

Estes JA, Tinker MT, Williams TM, Doak DF (1998) Killer whale predation on sea otters linking oceanic and nearshore ecosystems. Science 282:473-476

Forrester G, Steele M (2004) Predators, prey refuges, and the spatial scaling of density-dependent prey mortality. Ecology 85:1332-1342

Garcia TS, Sih A (2003) Color change and color dependent behavior in response to predation in the salamander sister species Ambystoma arbouri and Ambystoma texanum. Oecologia 137:131-139

> Halpern BS, Cottenie K, Broitman BR (2006) Strong top-down control in Southern California kelp forest ecosystems. Science 312:1230-1232

> Herrnkind WF, Childress MJ, Lavalli KL (2001) Cooperative defense and other benefits among exposed spiny lobsters: 
inferences from group size and behavior. Mar Freshw Res 52:1113-1124

Holbrook S, Schmitt R (1988) The combined effects of predation risk and food reward on patch selection. Ecology 69: 125-134

Hovel KA, Lipcius RN (2001) Habitat fragmentation in a seagrass landscape: Patch size and complexity control blue crab survival. Ecology 82:1814-1829

Kelly S, MacDiarmid AB, Babcock RC (1999) Characteristics of spiny lobster, Jasus edwardsii, aggregations in exposed reef and sandy areas. Mar Freshw Res 50:409-416

Kie J (1999) Optimal foraging and risk of predation: effects on behavior and social structure in ungulates. J Mammal 80: $1114-1129$

Kulbicki M (1998) How the acquired behavior of commercial reef fishes may influence the results obtained from visual censuses. J Exp Mar Biol Ecol 222:11-30

Lindberg RG (1955) Growth, population dynamics and field behavior of the spiny lobster, Panulirus interruptus. Univ Calif Publ Zool 59:157-247

Lipcius RN, Eggleston DB, Miller DB, Luhrs TC (1998) The habitat-survival function for Caribbean spiny lobster: an inverted size effect and non-linearity in mixed algal and seagrass habitats. Mar Freshw Res 49:807-816

MacLulich DA (1937) Fluctuations in the numbers of varying hare (Lepus americanus). Univ Toronto Stud Biol Ser 43: $1-136$

Mai T, Hovel KA (2007) Influence of local-scale and landscape-scale habitat characteristics on California spiny lobster (Panulirus interruptus) abundance and survival. Mar Freshw Res 58:419-428

$>$ Micheli F (1997) Effects of predator foraging behavior on patterns of prey mortality in marine soft bottoms. Ecol Monogr 67:203-224

Mintz JD, Lipcius RN, Eggleston DB, Seebo MS (1994) Survival of juvenile Caribbean spiny lobster: effects of shelter size, geographic location and conspecific abundance. Mar Ecol Prog Ser 112:255-266

Mitchell C, Turner CH, Strachan AR (1969) Observations on the biology and behavior of the California spiny lobster, Panulirus interruptus (Randall). Calif Fish Game 55: 121-131

Nevitt G, Pentcheff DN, Lohmann KJ, Zimmer RK (2000) Den selection by the spiny lobster Panulirus argus: testing attraction to conspecific odors in the field. Mar Ecol Prog Ser 203:225-231

Nichols KD (2009) The effects of predators and habitat on sea urchins in southern California. MS thesis, San Diego State University, San Diego, CA

>rth RJ, van Montfrans J (2002) Habitat quality and prey size at determinants of survival in post-larval and early juvenile instars of the blue crab Callinectes sapidus. Mar Ecol Prog Ser 231:205-213

Paddack MJ, Estes JA (2000) Kelp forest fish populations in marine reserves and adjacent exploited areas of central California. Ecol Appl 10:855-870

Paine RT (1974) Intertidal community structure: experimental studies on the relationship between a dominant competitor and its principal predator. Oecologia 15:93-120

Parker KP (1972) Recruitment and behavior of puerulus larvae and juveniles of the California spiny lobster Panulirus interruptus (Randall). MS thesis, San Diego State University, San Diego, CA

Parnell E, Lennert-Cody C, Geelen L, Stanley L, Dayton P

Editorial responsibility: Romuald Lipcius,

Gloucester Point, Virginia, USA
(2005) Effectiveness of a small marine reserve in southern California. Mar Ecol Prog Ser 296:39-52

- Peterson CH, Black R (1994) An experimentalist's challenge: when artifacts of intervention interact with treatments. Mar Ecol Prog Ser 111:289-297

Pile AJ, Lipcius RN, Montfrans JV, Orth RJ (1996) Densitydependent settler-recruit-juvenile relationships in blue crabs. Ecol Monogr 66:277-300

Robles C, Sweetnam D, Eminike J (1990) Lobster predation on mussels: shore-level differences in prey vulnerability and predator preference. Ecology 71:1564-1577

Ryer C (1988) Pipefish foraging: effects of fish size, prey size and altered habitat complexity. Mar Ecol Prog Ser 48: $37-45$

Seghers B (1974) Schooling behavior in the guppy (Poecilia reticulate): an evolutionary response to predation. Evolution 28:486-489

Serfling SA (1972) Recruitment, habitat preference, abundance, and growth of the puerulus and early juvenile stages of the California spiny lobster, Panulirus interruptus (Randall). MSc thesis, San Diego State University, San Diego, CA

Smith KS, Herrnkind WF (1992) Predation on early juvenile spiny lobsters Panulirus argus (Latreille): influence of size and shelter. J Exp Mar Biol Ecol 157:3-18

Spanier E, Zimmer-Faust RK (1988) Some physical properties that influence den preference in spiny lobsters. J Exp Mar Biol Ecol 121:137-149

Spanier E, McKenzie TP, Cobb JS, Clancy M (1998) Behavior of juvenile American lobsters, Homarus americanus, under predation risk. Mar Biol 130:397-406

Stein R (1977) Selective predation, optimal foraging and the predator-prey interaction between fish and crayfish. Ecology 58:1237-1253

Stewart JG (1991) Marine algae and seagrasses of San Diego County. California Sea Grant Publication, University of California, La Jolla, CA

> Tegner MJ, Dayton PK (1981) Population structure, recruitment, and mortality of two sea urchins (Strongylocentrotus fransciscanus and $S$. purpuratus) in a kelp forest near San Diego, California. Mar Ecol Prog Ser 5:255-268

Tegner MJ, Levin LA (1983) Spiny lobsters and sea urchins: analysis of a predator-prey interaction. J Exp Mar Biol Ecol 73:125-150

Vucetich J, Smith D, Stahler D (2005) Influence of harvest, climate and wolf predation on Yellowstone elk. Oikos 111: $259-270$

Winget RR (1968) Trophic relationships and metabolic energy budget of the California spiny lobster, P. interruptus. MS thesis, San Diego State University, San Diego, CA

Withy-Allen KW (2010) California spiny lobster (Panulirus interruptus) movement behavior and habitat use: implications for the effectiveness of marine reserves in southern California. MS thesis, San Diego State University, San Diego, CA

Zar JH (1999) Biostatistical analysis. Prentice Hall, Upper Saddle River, NJ

Zimmer-Faust RK, Spanier E (1987) Gregariousness and sociality in spiny lobsters: implications for den habitation. J Exp Mar Biol Ecol 105:57-71

Zimmer-Faust RK, Tyre JE, Case JF (1985) Chemical attraction causing aggregation in the spiny lobster Panulirus interruptus, and its probable ecological significance. Biol Bull 169:106-118

Submitted: September 15, 2010; Accepted: September 28, 2010 Proofs received from author(s): December 1, 2010 